加我君孝，進藤美津子（帝京大耳鼻科）

左右の大脳半球をつなぐ脳梁に関する研究は、視覚, 運動行為に関するものが多く、聴 覚につんては数が少ない。脳梁の聴覚神経線維は, 脳梁幹の後部あるいは膨大部に位置す

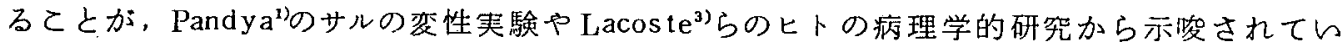
る。しかし、その機能は，未だ明らかではなく，CV音節や数字に上る阔耳㯖検査で左耳が 低下することが知られている程度である2。

われわれは、脳梁幹部より膨大部の一部が手術で切断された 1 症例につんて, 脳梁にお ける神経線維の役割につんて検討すへく聴覚心理・生理学的に調べたので報皆する。

1. 症例 47 才 女主婦 右利を

主挀：左耳の異和感

1988 年 3 月 13 日。突然, めい感と軽度の右片麻瘏が出現した。しかし，神経症状は。 間も無く消失した。同月，帝京大脳外科にて入院精査したとてろ，左側脳空に石灭化した 腫瘍陰影が見出された。同年 5 月, 左側脳室三角部の髄膜腫の摘出術を行った。そのさん に腫痬摘出のために脳梁幹を切断した。術後一時的に軽辰の右片麻㽻が出現したが，その

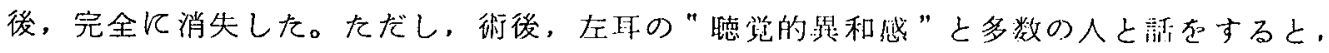
術前に比し集中力の維持が困難であると訴えた。

\title{
2. 検查所見：
}

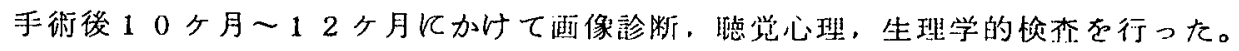

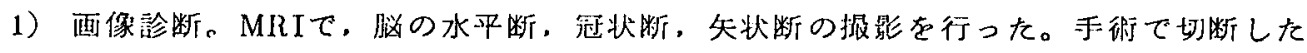
脳梁は, 幹の後半部の $1 / 2$ と膨大部の幹に近いー部が切断されていた。

2) 聴覚心理学的検查

純音聴力検査では, 左右とも正常箅四の間值を示した。語音明暸度検查（５７式）

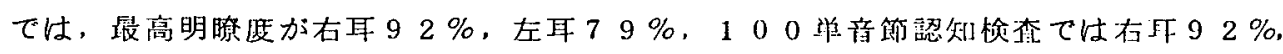
左耳 $82 \%$ と左耳の軽度の低下を認めた。3桁の数字の両耳分離能テスト (Dichotic Listening Test-DLT) では，右耳が99\%，左耳が $12 \%$ と著しい左右差を示した。 方向感自動記録装固を用いた時間差音像定位検査では軽传の振幅の增大を認めた。

3) 聴覚生理学的検査

左右耳別に聼性誘発反応検查を行った。聴性脳幹反応, 中間潜時反応, 䌅反応の々

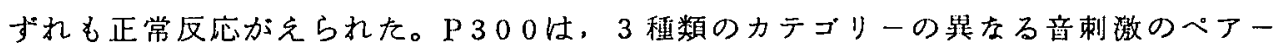
を用いて, 左右耳別に検査を行った。すなわち, 純音は $1 \mathrm{KHz} v 2 \mathrm{KHz}$, 哣音は, 单 語が aka vs kuro, 単音節がpa vs baのベアーを刺激とした。その結果, 䊶音と笚語刺 激では,P３００が出現した。単音節刺激では，N450，P600が再現性良く出現した。 3. 考察 :

本例の䠄梁切断部位は, 脳梁幹後部から膨大部の一部にかかるもので,サルの先験や， 臨床例の病理学的研究から聴覚の神経線維の走行が存在すると示唆された部位と一致する。 聴覚心理学的検査では, 従来の報告と同様に左耳の分離能の著しい低下を示した。同時に 本例では左耳の語音明暸度が軽度低下していた。一方, 聴性誘発反応が左右差なく, 事象 
関連電位検査では䊶音，語音の刺激でP300あるいはN450が良好に出現しているととは， てれらの刺激音にたんしては生理学的には認知機能は良好であるとを示している。

聴覚心理学的検査で生じた左右差は次のよ5に説明できるであろう。すなわち, 語音は 右耳に入ると, 聴覚情報は、脳幹の上オリーブ核で交叉したあと左大脳半球に到達し、言 語中枢を介して認知されるが，左耳に入ると右大脳半球の聴皮質に到達し，そてから，脳 梁を経て左大脳半球に入り認知される。しかし本例では, 脳梁の聴覚線維が切断されてい るために, 左耳の検查成績が低下するのであろら。しかし, 語音の明瞭度検查の左右差が $13 \%$ あのに対し, D L Tでは $87 \%$ も差を示す。てのてとは, 脳梁の聴觉線維は, 片耳づつの語音の情報処理よりも, 耐耳同時刺激のような; 賠合状柋における情報処理に 重要な役割をしているととを示唆している。

\section{引用文献：}

1. Pandya DN, et al:The topographic distribution of interhemispheric projections in the corpus callosum of the rhesus monkey. Brain Res $32: 31-43$, 1971.

2. Springer SP, Gázzaniga MS :

Dichotic testing of partial and complete split brain subjects. Neuropsychologia $13: 341-346,1975$.

3. Lacoste MC, et al :Topography of the human corpus callosum. J. Neuropath \& Exp. Neurol. 44:578-591, 1985.

4. $\Lambda$ lexander MP, et al :Localization of callosal anditory pathways $: \Lambda \mathrm{CT}$ case study. Neural $38: 802-804,1988$.

\begin{tabular}{lllll} 
Year & \multicolumn{1}{c}{ Author } & \multicolumn{1}{c}{ Callosal Section } & Dichotic Listening test & Extinction Ear \\
\hline 1968 & Sparks \& Geschwind & \multicolumn{1}{c}{ ? } & digits, animal names & left \\
1975 & Springer \& Gazzaniga & anterior to splenium & consonant-vowel & left \\
1980 & Damasio et al & splenium & ? & none \\
1980 & Geffen et al & posterior & target detection & left \\
1985 & Jun et al & 2cm anterior to splenium & consonant-vowel & left \\
1985 & Sugishita et al & upper splenium & consonant-vowel & left \\
1985 & Gazzaniga et al & truncus \& splenium & consonant-vowel & left \\
1988 & Alexander et al & posterior body & words & left \\
\hline
\end{tabular}

